\title{
Editorial
}

\section{Quando a Pandemia Passar}

Espectros que nos remetem ao passado assustam nosso cotidiano - uma mortífera pandemia, a destruição dos direitos sociais e trabalhistas conquistados com muita luta, o retorno de milhões à miséria, a ampliação da dependência nacional e um governo irresponsável.

Ocorre agora no mundo e, em particular, no Brasil, a radicalização extremada do neoliberalismo da década de 1980. Pior, a direita ultraneoliberal, que atualmente comanda esta pauta, conseguiu destruir a capacidade do Estado de acudir a sociedade - onde há tentativas de enfrentamento da pandemia, fica-se à mercê de multinacionais farmacêuticas que estabelecem preços e prazos ou fixam as regras de aprovação das vacinas.

Como diz o sociólogo Boaventura de Sousa Santos, os ultraneoliberais usam a ficção da crise financeira permanente para explicar os cortes nas políticas sociais e a degradação dos salários, mas seus objetivos vão bem mais longe - legitimar a escandalosa concentração de riqueza e espoliar o planeta, pouco importando a catástrofe ecológica grave e iminente.

Antes da pandemia, o Brasil já afundava no desemprego e na crise política e econômica, alimentada pelos golpistas das operações de espionagem, lawfare, impeachment e fraude jurídico-eleitoral desenvolvidas entre 2013 e 2018. Ao mesmo tempo, sob o pretexto do avanço tecnológico, promovia-se a economia da precarização e da uberização. Desde o início da pandemia, tal processo foi intencionalmente acelerado. 
Sabemos que, apesar do governo brasileiro, a pandemia também será vencida aqui, ainda que custe centenas de milhares de vidas que poderiam ter sido poupadas. Mas, nada era ou será normal. A crise continuará e só há solução para a maioria da sociedade se a extrema-direita e a direita ultraneoliberal deixarem o poder.

Contudo, para haver futuro é preciso muito mais: redemocratização do país e mudança do projeto de desenvolvimento, com valorização do trabalho, desenvolvimento sustentável, investimento maciço em educação e tecnologia a serviço da sociedade e da redução da jornada laboral, energias renováveis, proteção à agricultura familiar e ecológica, reconstrução das agendas sociais e trabalhistas, renda mínima, redução das desigualdades etc.

Como dissemos há um ano, é preciso que continuemos a semear em meio à tempestade. Somos todos semente desse futuro.

Nesta edição, a revista Laborare, editada pelo Instituto Trabalho Digno, reúne 12 artigos que muito contribuem para o conhecimento multidisciplinar do mundo do trabalho. Os advogados Diego Villalón e Paulo Yamamoto analisam como o "pandemônio neoliberal" atuou durante a pandemia no Chile e no Brasil, e tratam de caminhos solidários trilhados pelo povo chileno. As professoras Alice Itani e Clarisse Castilhos, por sua vez, indagam como o discurso do desenvolvimento, imposto aos países do Sul, repercutem na vida e no trabalho.

A Covid-19 também está presente no artigo do juiz do trabalho Xerxes Gusmão, do Espírito Santo, que questiona as modificações normativas adotadas no Brasil, uma vez que, ao contrário do que era preciso, flexibilizou-se a proteção à saúde e segurança do trabalho. O auditor-fiscal do trabalho Rui Vidal, da Paraíba, aborda a caracterização do risco grave e iminente na realidade sanitária da pandemia, assumindo que muitas irregularidades nos canteiros de obra passaram a significar excesso de risco à saúde dos 
trabalhadores, justificando-se a paralisação temporária da obra.

O professor Nilton Vasconcelos, explora aspectos pouco conhecidos sobre experiências associativas e no surgimento do cooperativismo na Bahia a partir do fim do século XIX. A professora Alessandra Bender, do Instituto Federal do Paraná (IFPR), aborda a relação entre a temática do trabalho e a educação profissional e destaca a formação dos trabalhadores como agentes de transformação social.

O pesquisador e sindicalista Remígio Todeschini apresenta sua pesquisa sobre os efeitos do trabalho de turno, demonstrando que no caso da quinta turma nas indústrias químicas de São Paulo, quanto mais dias de folgas e adicionais financeiros de turno, haverá menos problemas de saúde física e mental, e melhoria no convívio social e familiar. As estudiosas de Saúde Mental Amanda Azambuja e Liliana Guimarães avaliaram os fatores psicossociais de risco relacionados ao trabalho em funcionários públicos estaduais em Mato Grosso do Sul, enfatizando a necessidade de medidas de proteção e promoção da sua saúde.

A pesquisadora da Fundacentro Maria Engrácia Chaves e a professora da UFBA Estela Aquino abordam a questão da desigualdade de gênero na reinserção no mercado de trabalho após a aposentadoria, quando mulheres que querem ou precisam voltar a trabalhar enfrentam obstáculos bem maiores que os enfrentados pelos homens. Também é sobre desigualdade no mercado de trabalho o estudo das advogadas Anna Beatriz Reis, Daiane Silva, Marcela Andrade e Monique Basso, de São Paulo, tratando das barreiras impostas às pessoas com deficiência e o direito ao trabalho como importante instrumento de emancipação.

Mazela de um passado que não passa, o trabalho infantil é estudado em dois artigos. A pesquisadora Elisa Vergara, de São Paulo, busca desvendar as razões pelas quais a regulação da exploração do trabalho infantil doméstico permanece à margem do 
sistema protetivo legal às crianças e adolescentes. O acadêmico Felipe Caetano da Cunha e as professoras Vanessa Sousa e Camilla Cavalcanti realizaram no Ceará o estudo do caso da explosão de uma fábrica de fogos em Santo Antônio de Jesus, Bahia, que matou 6sessenta pessoas, dentre as quais vinte crianças e adolescentes que exerciam uma das piores formas de trabalho infantil, analisando-o à luz dos Direitos e da Convenção sobre os Direitos das Crianças.

Como dissemos há um ano, é preciso que continuemos a semear em meio à tempestade. Somos todos sementes desse futuro.

Boa leitura!

\section{Os Editores}

